\title{
Responses of Performance and Microbial Community to Long-Term Graphene Oxide Exposure in a Sequencing Batch Reactor
}

\author{
Jinghou Wang ${ }^{1 \#}$, Liqiu Zhang ${ }^{2,3 \#}$, Shaoqing Zhang ${ }^{3}$, Shugeng Li ${ }^{1,2 *}$, Hainan Yao ${ }^{3}$ \\ ${ }^{1}$ School of Environmental Science and Engineering, Guangzhou University, Guangzhou 510006, PR China \\ ${ }^{2}$ Key Laboratory for Water Quality and Conservation of the Pearl River Delta, Ministry of Education, \\ Guangzhou University, Guangzhou 510006, PR China \\ ${ }^{3}$ School of Civil Engineering, Guangzhou University, Guangzhou 510006, PR China
}

Received: 31 December 2019

Accepted: 20 March 2020

\begin{abstract}
The widespread use of graphene oxide (GO) raises environmental concerns. Municipal wastewater treatment systems are potential receptors of GO containing streams, yet the influences of chronic toxicity of GO on these systems are poorly understood. In the present study, the responses of nutrient removal performance and microbial community to long-term GO exposure were investigated. The results showed that reduction in performance of COD, ammonia and phosphate removals was observed during the whole experiment. The highest effluent COD contents $56.07 \mathrm{mg} / \mathrm{L}$ occurred when influent GO concentration was $30 \mathrm{mg} / \mathrm{L}$. Low concentration of GO $(1-10 \mathrm{mg} / \mathrm{L})$ had a greater impact on ammonia and phosphate removal performance, the highest effluent concentration of ammonia and phosphate was $9.51 \mathrm{mg} / \mathrm{L}$ and $2.72 \mathrm{mg} / \mathrm{L}$. However, there was a certain recovery trend of removal efficiency in each concentration gradient. The results of $16 \mathrm{~S}$ rRNA gene sequencing showed that long-term GO exposure significantly altered the composition and structure of activated sludge microbial communities. Specifically, both bacterial richness and evenness indexes decreased as the GO concentration increased. Significant shift of bacterial community structures was observed after GO addition and then recover slightly at recovery stage without GO addition. Moreover, functional bacteria, such as Dechloromonas, Nitrosomonas, Nitrospira, Defluviicoccus, and Chryseobacterium were significantly shifted, which may be associated with altered nutrient removal performances and EPS production. And protein content in EPS varied between $103.54 \mathrm{mg} / \mathrm{L}$ and $206.84 \mathrm{mg} / \mathrm{L}$. The findings in this study provide new insights into our understanding of the potential effects of long-term GO exposure on wastewater treatment systems.
\end{abstract}

Keywords: graphene oxide, chronic toxicity, activated sludge, functional bacteria, community structure 


\section{Introduction}

Due to the unique physical and chemical properties, graphene oxide (GO) have been widely used in multifunctional sensor materials [1, 2], drug carrier [3, 4], adsorbent material [5-7]. The discharge GO during their production and use inevitably lead to the wastewater with GO entering the sewage treatment process. Moreover, GO was widely used as adsorbent in wastewater treatment systems for removal of heavy metal $[8,9]$, organic dye [10] and refractory organic matters [11]. However, GO has biological toxicity [12] and antibacterial properties [13]. Reactor performance and microbial communities of sewage treatment systems could be influenced because of the existing GO. Therefore, the impact of GO on performances reactor of sewage treatment systems should be a comprehensively evaluated.

The cytotoxicity of GO has been extensively studied in culture system for pure cells. For example, the toxicity of GO has been demonstrated to be related to the particle size, oxygen content, exposure environment of red blood cells [14]. In addition, the decreased oxidation degree of GO led to a higher degree of cytotoxicity $[15,16]$. On the contrary, a study indicated that one kind graphene oxide polymer had no conspicuous cytotoxicity to murine macrophages [17]. However, the findings obtained in the studies employed culture systems cannot be generalized to complex microbial communities such as activated sludge systems. Moreover, when the concentration of GO achieved at a low range $(50-100 \mathrm{mg} / \mathrm{L}), \mathrm{GO}$ could play a facilitating role in nitrogen removal system [18].

At present, the cytotoxicity of GO has been widely studied in activated sludge systems [13], soil microbial communities [19]. Akhavan et al. [20] that the graphene oxide nanowalls have toxic to Gram-negative Escherichia coli bacteria. Nguyen et al. [21] investigated the cytotoxicity of 1 and $5 \mathrm{mg} / \mathrm{L}$ of GO during 10 days in activated sludge, the results suggested that impact of GO in nutrient removal and transformations in microbial communities was significant. Liu et al. [22] mentioned, $0.06 \mathrm{~g} / \mathrm{L}$ GO might conquer bioactivity of phosphorusaccumulating organisms in activated sludge system, the text sustained a few hours. However, not all research results were negative, Guo [23] recommended that GO could be combined with sludge perfectly and promoted the bioactivities of some functional bacteria. Ahmed [24] demonstrated that in the activated the presence of GO influenced metabolic activity and viability of the bacterial, in concentration between 5 and $300 \mathrm{mg}$ $\mathrm{GO} / \mathrm{L}$. Overall, the previous study indicated that shortterm GO exposure could have different effects on microorganisms, i.e., low concentration of GO might have positive impact on nitrogen removal, while high concentration of GO would inhibit the activity of microorganisms. However, GO could adsorb on the sludge [25] and the SRT is longer about 10-25 days [26]. Therefore, GO might accumulate in the sludge have chronic effects on biological treatment systems. Longterm GO exposure is rarely reported.Therefore, the aim of this study is to investigate the impact of long-term GO exposure on rector performance and microbial structure and abundance of sewage treatment system. To achieve these goals, SBR reactors was used. The concentration of GO was set as $1,2,5,10,15,30,60,80 \mathrm{mg} / \mathrm{L}$ and Without GO, and each concentration lasted 10 cycles. The purpose was to determine the relationship between the accumulation of graphene oxide in activated sludge and the change of effluent, and the changes in microbial diversity structure and abundance.

\section{Materials and Methods}

\section{Preparation and Characteristics of GO}

The purchased GO aqueous solution purchased from Nanjing XFNANO Materials Tech Co., Ltd has a concentration of $2000 \mathrm{mg} / \mathrm{L}$. The $\mathrm{GO}$ has a single layer ratio of about $99 \%$, a thickness of 0.8 to $1.2 \mathrm{~nm}$, a purity of about $99 \%$, and a sheet diameter of less than $500 \mathrm{~nm}$. The GO solution was stored in dark. The different dosage of GO solution was added to prepare different concentration influent in the experiment (Table 1). GO in the supernatant were quantified using a UV-Visible spectrophotometer (UV-2550, Shimadzu, Japan) with minimum detection limit of $1 \mathrm{mg} / \mathrm{L}$. To avoid interference from the background of the biomass supernatant, a wavelength of $300 \mathrm{~nm}$ was used for GO quantification [27].

\section{Reactor Setup}

Two identical SBR reactors were set up, one for the test group and the other for the control group. Both reactors were seeded with activated sludge obtained from a secondary clarifier of a Lek Kok Sewage Treatment Plant (Guangzhou, China). The working volume was $4 \mathrm{~L}$ with a cylindrical part height of $310 \mathrm{~cm}$, lower cone height of $90 \mathrm{~cm}$ and an inner diameter of $15 \mathrm{~cm}$. The SBR was worked at $26 \pm 2^{\circ} \mathrm{C}$ with two cycles each day. Each cycle was consisted of $120 \mathrm{~min}$ anaerobic stage, $240 \mathrm{~min}$ aerobic stage, $30 \mathrm{~min}$ settle time, $10 \mathrm{~min}$ draw and about $5.3 \mathrm{~h}$ idle. Drainage ratio was $50 \%$. The hydraulic retention time (HRT)

Table 1. GO concentrations in different cycles.

\begin{tabular}{|c|c|c|c|c|c|c|c|c|c|}
\hline Cycle & $1-10$ & $11-20$ & $21-30$ & $31-40$ & $41-50$ & $51-60$ & $61-70$ & $71-80$ & $81-90$ \\
\hline Concentration $(\mathrm{mg} / \mathrm{L})$ & 1 & 2 & 5 & 10 & 15 & 30 & 60 & 80 & Without GO \\
\hline
\end{tabular}


Table 2. Composition of synthetic wastewater.

\begin{tabular}{|c|c|c|c|}
\hline Ingredients & Concentration $(\mathrm{mg} / \mathrm{L})$ & Ingredients & Concentration $(\mathrm{mg} / \mathrm{L})$ \\
\hline $\mathrm{NH}_{4}^{+}-\mathrm{N}$ & $23.99 \sim 30.95$ & $\mathrm{COD}$ & $288.36 \sim 301.71$ \\
\hline $\mathrm{NO}_{3}^{-}-\mathrm{N}$ & $0.92 \sim 1.73$ & $\mathrm{PO}_{4}{ }^{3-}$ & $2.42 \sim 3.42$ \\
\hline $\mathrm{NO}_{2}^{-}-\mathrm{N}$ & $0 \sim 0.087$ & & \\
\hline
\end{tabular}

Note: $\mathrm{pH}$ was $7.3 \sim 7.6$.

was set at $6.5 \mathrm{~h}$ and the sludge retention time (SRT) was set at $20 \pm 2$ days, MLSS was maintained at $4500 \pm 450 \mathrm{mg} / \mathrm{L}$ with $200 \mathrm{~mL}$ mixed liquor discharging from the reactor per day. The reactors were fed with synthetic wastewater (Table 2) in the first $1 \mathrm{~min}$ of the anaerobic stage every $12 \mathrm{~h}$. COD was supplemented with glucose in synthetic wastewater. The reactor $\mathrm{pH}$ was adjusted to 7.0 by adding $\mathrm{NaHCO}_{3}$ and $3 \mathrm{M}$ $\mathrm{HCl}$. In the aerobic phase, the aerated air flow rate was $40 \mathrm{~L} / \mathrm{h}$ to maintain simultaneous phosphate and nitrogen removal. Both reactors were pre-cultivated for 10 days to achieve stable activity. Afterward, they were operated for 90 cycles, along with GO added to test reactor (Table 1) and without GO adding for control reactor.

\section{Chemical Parameter Analysis}

For each cycle, the effluent of two reactors was analyzed for the following parameters: ammonia $\left(\mathrm{NH}_{4}^{+}-\mathrm{N}\right)$, total nitrogen $(\mathrm{TN})$, phosphate $\left(\mathrm{PO}_{4}^{3-}\right)$, and chemical oxygen demand (COD). After collected, influent and effluent were filtered through $0.1 \sim 0.3 \mu \mathrm{m}$ qualitative filter paper (Sangon Biotech, Shanghai. Co., Ltd.). $\mathrm{NH}_{4}^{+}-\mathrm{N}, \mathrm{PO}_{4}^{3-}$ and nitrite nitrogen were analyzed according to the national standard methods [28] using UV-2550 uv-visible spectrophotometer (SHIMADZU). All chemical indicators were in the unit of $\mathrm{mg} / \mathrm{L}$.

\section{Extracellular Polymeric Substances (EPS) Analysis}

EPS was excecated using modified heat extraction $[29,30]$. All samples were taken from the end of the anaerobic phase at the end of each concentration gradient. At the end of a cycle, $10 \mathrm{~mL}$ of the mixed liquor in the reactor was taken with a $10 \mathrm{~mL}$ syringe and transferred to a $15 \mathrm{~mL}$ centrifuge tube. After the precipitation for $10 \mathrm{~min}$, the supernatant was decanted, and the sludge was washed three times with $10 \mathrm{~mL}$ of phosphate buffered saline (PBS) (30 min once). The volume was adjusted to $10 \mathrm{~mL}$, and the mixture was centrifuged at $4^{\circ} \mathrm{C}, 4000 \mathrm{rpm}$ for $20 \mathrm{~min}$, and the supernatant was collected (dissolved EPS). The sludge was resuspended in $10 \mathrm{~mL}$ of pure water, and $4 \mathrm{~mL}$ of a $1 \mathrm{~mol} / \mathrm{L}$ sodium hydroxide solution was added and stored at $4^{\circ} \mathrm{C}$ for 3 hours. Then, the mixture was stirred for 35 minutes at $400 \mathrm{rpm}$ and $80^{\circ} \mathrm{C}$. Finally, high- speed centrifugation $\left(10000 \times \mathrm{g}, 20 \mathrm{~min}, 4^{\circ} \mathrm{C}\right)$ was used to extract the combined extracellular polymer.

The supernatant was used for EPS chemical composition analysis. Particulates in samples were removed using a $0.45 \mu \mathrm{m}$ polytetrafluoroethylene (PTFE) membrane prior to EPS chemical composition analysis. EPS included protein (PN) and polysaccharide (PS). With Modified BCA Protein Assay Kit (Sangon Biotech, Shanghai. Co., Ltd.) and phenol-sulphuric acid method, the PN and PS contents were also analyzed by UV-vis spectrophotometry [31].

\section{DNA Extraction and Quantitative Real-Time PCR (q-PCR)}

Biomass samples from the test reactor were collected at the end of the anaerobic phase at the end of each concentration gradient. Using filter paper $(11 \mathrm{~cm}$, $45 \mu \mathrm{m})$ to filter the obtained mixed liquid sludge samples and weighed $0.25 \mathrm{~g}$ for DNA extraction. Extraction of DNA using the Power Soil DNA Isolation Kit (Mobio, USA).

The q-PCR was guided by using q-PCR kit (SYBR Green PCR master mix, Sangon Biotech (Shanghai), China) in term of the manufacturer's instructions on StepOne Plus Real-Time PCR System (Applied Biosystems, Thermofisher, USA). We evaluated three functionally genes amoA (ammonia monooxygenase), Nitrospira and nirS (nitrite reductase). The specific primer for amplification of gene amoA were CTO189fA/B ${ }^{\mathrm{b}}$ (GGAGRAAAGCAGGGGATCG), CTO189fC $^{\mathrm{b}}$ (GGAGGAAAGTAGGGGATCG) and RT1r (CGTCCTCTCAGACCARCTACTG) [32]. The specific primer sets for amplification of Nitrospira gene were NSR1113f (CCTGCTTTCAGTTGCTACCG) and NSR1264r (GTTTGCAGCGCTTTGTACCG)[33]. The specific primer for amplification of gene nirS were Cd3aF (GTSAACGTSAAGGARACSGG) [34] and R3cdR (GASTTCGGRTGSGTCTTGA) [35]. A $25 \mu \mathrm{l}$ reaction system was set up for each PCR amplification, including 9.5 $\mu \mathrm{l} \mathrm{DEPC} \mathrm{treatment} \mathrm{water,} 1 \mu \mathrm{l}$ forward primer, $1 \mu \mathrm{l}$ reverse primer and $12.5 \mu \mathrm{l}$ SYBR. The amplification program for amoA consisted of an initial denaturation step at $95^{\circ} \mathrm{C}$ for $4 \mathrm{~min}, 40$ cycles of denaturation at $95^{\circ} \mathrm{C}$ for $15 \mathrm{~s}$, annealing at $61^{\circ} \mathrm{C}$ for $30 \mathrm{~s}$ and followed by extension at $72^{\circ} \mathrm{C}$ for $1 \mathrm{~min}$. The amplification program for Nitrospira consisted of an initial denaturation step at $95^{\circ} \mathrm{C}$ for $5 \mathrm{~min}, 40$ cycles 
of denaturation at $95^{\circ} \mathrm{C}$ for $15 \mathrm{~s}$, annealing at $60^{\circ} \mathrm{C}$ for $30 \mathrm{~s}$ and followed by extension at $72^{\circ} \mathrm{C}$ for $1 \mathrm{~min}$. The amplification program for nirS consisted of an initial denaturation step at $95^{\circ} \mathrm{C}$ for $4 \mathrm{~min}, 40$ cycles of denaturation at $98^{\circ} \mathrm{C}$ for $10 \mathrm{~s}$, annealing at $60^{\circ} \mathrm{C}$ for $30 \mathrm{~s}$ and followed by extension at $72^{\circ} \mathrm{C}$ for $1 \mathrm{~min}$.

\section{Metagenomic Classification and Sequencing}

The changes in the microbial community exposed to nanomaterial different concentrations of GO and recovery phase were analyzed using deep sequencing 16S rRNA to understand the chronic toxicity of different concentrations of $\mathrm{GO}$ on microorganisms in the reactor. DNA samples were extracted using the E.Z.N.A.TM Soil DNA Kit (Omega Bio-tek, Inc. USA). Genomic DNA was accurately quantified using the Qubit 3.0 DNA Assay Kit to determine the amount of DNA that should be added to the PCR reaction. The primers (341F Primer: CCCTACACGACG CTCTTCCGATCTG (barcode) CCTACGGGNGGCW GCAG, 805R Primer: GACTGGAGTTCCTT GGCACCCGAGAATTCCAGACTACHV GGGTAT CTAATCC) used in PCR have been fused to the V3-V4 universal primers of the Miseq sequencing platform. Two rounds of DNA amplification were according to the protocol described in the preparation of the 16S rRNA Metagenomics sequencing library in the Illumina protocol. For PCR products amplified by bacteria and archaea and normal amplified fragments, the PCR product of $400 \mathrm{bp}$ or more was treated with 0.6 times of magnetic beads (Agencourt AMPure XP). The recovered DNA was accurately quantified using the Qubit 3.0 DNA Assay Kit to facilitate sequencing in an equal amount of 1:1. When mixed in equal amounts, the amount of DNA per sample was $10 \mathrm{ng}$, and the final sequencing concentration was 20 pmol. The DNAamplified samples were sequenced using an Illumina MiSeq sequencer.

\section{Results and Discussions}

$$
\begin{gathered}
\text { Impact of } \mathrm{GO} \text { on } \mathrm{COD}, \mathrm{NH}_{4}^{+}-\mathrm{N}, \mathrm{TN} \text { and } \mathrm{PO}_{4}^{3-} \\
\text { Removal }
\end{gathered}
$$

In biological treatment, COD was not only a means to determine the quality of biological processes, but also to reflect the activity of activated sludge [36]. Table S1 shows GO had a great impact on COD, TN and
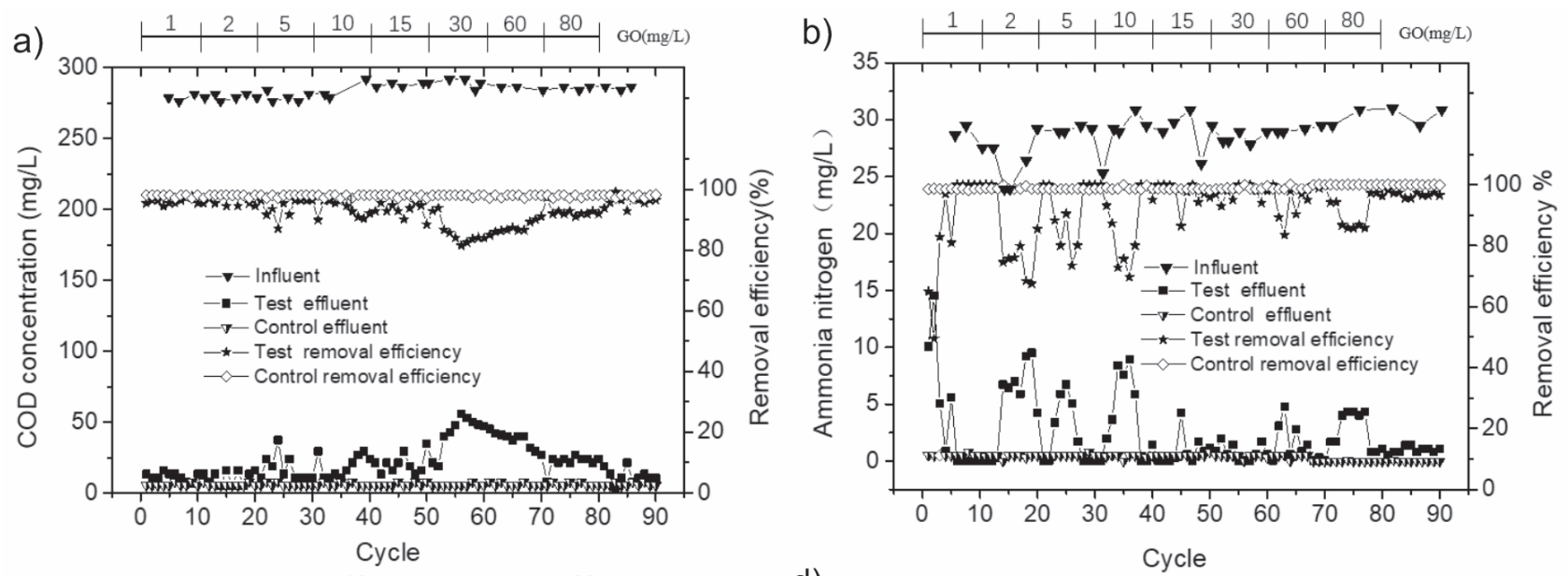

c)

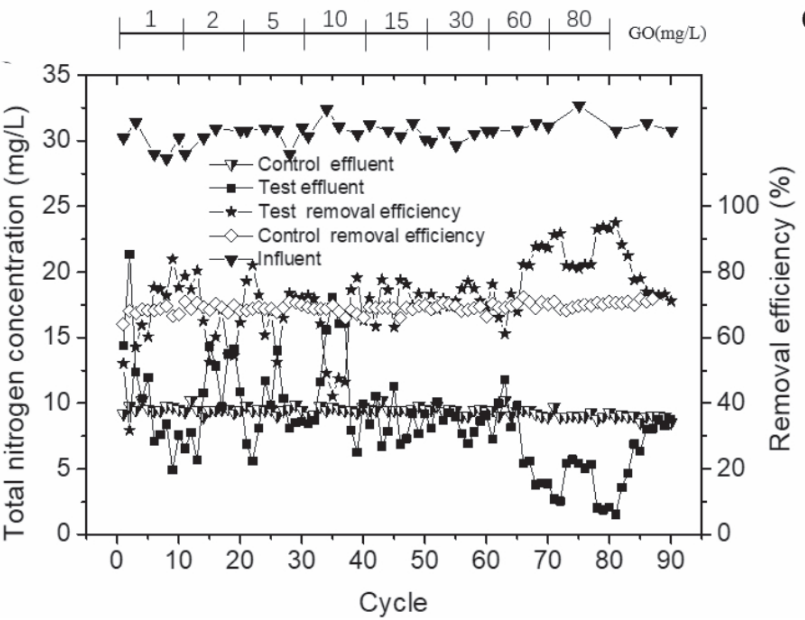

d)

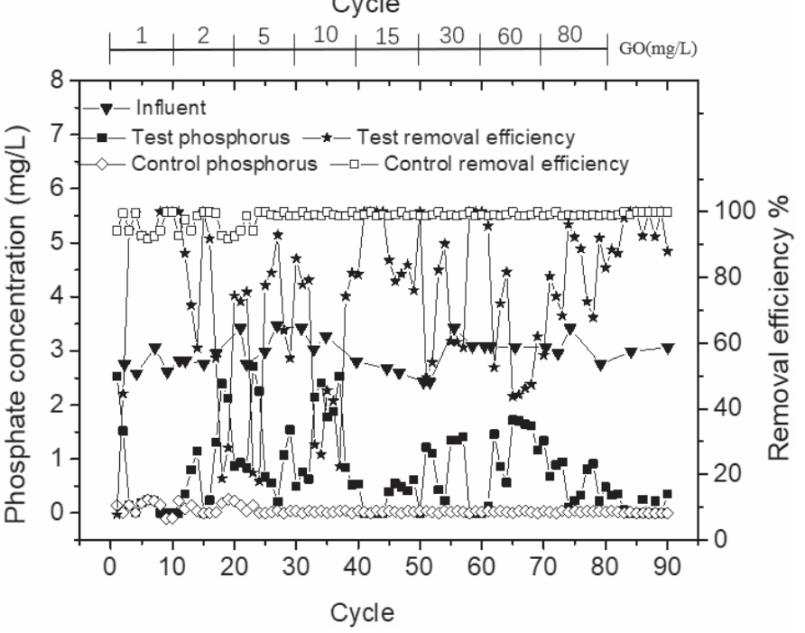

Fig. 1. $\mathrm{COD}$ a), $\mathrm{NH}_{4}^{+}-\mathrm{N}(\mathrm{b}), \mathrm{TN}$ c) and $\mathrm{PO}_{4}^{3-}$ d) in the influent and effluent of controls and reactors treated with different concentrations of GO. 
P concentration $(P<0.01)$. Fig. 1a) shows COD changes in the test group and the control. As seen in Fig. 1a), the COD of the control group was stable at around $5 \mathrm{mg} / \mathrm{L}$ from the end of set-up and removal efficiency of COD was up to $98 \%$. Almost all the effluent COD of the experimental group was higher than the control group, apart from one data point at recovery phase, and it was $2.67 \mathrm{mg} / \mathrm{L}$. When the concentration of GO was $5 \mathrm{mg} / \mathrm{L}, \mathrm{COD}$ in the effluent increased and then decreased after five cycles, and the peak value was $37.38 \mathrm{mg} / \mathrm{L}$ (the GO accumulate in activity sludge was $24 \mathrm{mg} / \mathrm{L}$ ), removal efficiency dropped to $87 \%$. From the $35^{\text {th }}$ to $39^{\text {th }}$ cycle, the effluent COD of the experimental group gradually increased, indicating that microbial activity in the activated sludge were gradually inhibited. As seen in Table S2, changes of GO could be reflected. During cycle 40-52, the average COD effluent decrease to $20.74 \mathrm{mg} / \mathrm{L}$, but obviously higher than control, removal efficiency was about $92 \%$. Then COD increase again, until cycle 56, the higher COD effluent was up to $56.07 \mathrm{mg} / \mathrm{L}$, and the GO accumulation in activated sludge was $135.67 \mathrm{mg} / \mathrm{L}$. After that, COD effluent decrease steadily until cycle 70 . Then even GO concentration increased to $80 \mathrm{mg} / \mathrm{L}$, COD kept stable at $20 \mathrm{mg} / \mathrm{L}$. When GO was no longer added, the COD of the experimental group in the effluent could gradually decreased and kept stable around $10 \mathrm{mg} / \mathrm{L}$.

The impacts on COD removals in activated sludge were previously reported with carbon-based nanomaterials in long- or short-term assays [21, 24, 37, 38]. For instance, acute toxicity studies with MWCNT and $G$ agreed with each other that low concentrations (1 $\mathrm{mg} / \mathrm{L})$ of these nanomaterials for short time did not impact COD removal $[37,38]$. Chronic study with continuously fed with GO or $\mathrm{G}$ showed that COD removal reduced significantly after nanomaterial accumulation in the activated sludge reached certain contents [39], which was consistent with our results. The initial low concentration of GO had little effect on COD removal efficiency. With the accumulation of GO in sludge, the influence gradually strengthened. However, due to the adaption of microorganisms to $\mathrm{GO}$, the influence decreased even when the influent GO concentration was higher than before (GO $80 \mathrm{mg} / \mathrm{L}$ )Nitrogen and phosphorus are the main factors that cause eutrophication of water bodies, so they are also two important nutrients that should be removed during biological wastewater treatment [40]. The operation mode of the reactor in this experiment was to provide the anaerobic and aerobic conditions of the activated sludge, so that the activated sludge absorbs excess phosphorus after releasing phosphorus. After anaerobic process, the aeration process helps to remove these pollutants in the form of ammonia $\left(\mathrm{NH}_{3}-\mathrm{N}\right)$ and phosphate $\left(\mathrm{PO}_{4}^{3-}\right)$. The effluent ammonia of control reactor was almost zero and removal efficiency of ammonia was more than $99 \%$. As to test group reactor, except for the first two cycles, the ammonia removal efficiency for all other cycles exceeded 60\% (Fig. 1b).
When the GO concentration was $2,5,10,60,80 \mathrm{mg} / \mathrm{L}$, for each stage, the ammonia nitrogen in the effluent rose to the peak and then decreases. The peak values were 9.51, 6.73, 8.96, 4.77 and $4.32 \mathrm{mg} / \mathrm{L}$, respectively. Peak decreasing indicated that the ammonia-oxidizing bacteria (AOB) in the activated sludge was adapting to the environment in which the GO existed, as evidenced by the EPS analysis - as the activated sludge adapted to the environment of $\mathrm{GO}$, the activated sludge under high concentration of $\mathrm{GO}$ did not produce excessive EPS (Fig. 2).

In order to show more detailed effects of $\mathrm{GO}$ on nitrogen removal, TN trends were shown in Fig. 1c). For control reactor, TN in effluent kept at $9.5 \mathrm{mg} / \mathrm{L}$, removal efficiency of which remained at $70 \%$. As for test reactor, when $\mathrm{GO}$ addition was $1,2,5$, and $10 \mathrm{mg} / \mathrm{L}$ in influent, $\mathrm{TN}$ in effluent increased firstly and then decreased to lower than control. When GO concentration was 15 to $80 \mathrm{mg} / \mathrm{L}$, most effluent TN concentration of test group reactor was lower than control. It is worth point out that lowest TN concentration occurred during GO was $80 \mathrm{mg} / \mathrm{L}$. During recovery stage (cycle 80-90), TN in test group recovered to the control. It could conclude that the negative effects of GO on denitrification was low and high concentration of GO could even promote the denitrification. Only when GO concentration was $10 \mathrm{mg} / \mathrm{L}$, denitrification was inhibited. Possible explanation may be the denitrifying bacteria was not inhibited by GO and GO could even increase the quantity of these microorganism, which was proved in the microbial communities' analysis.

Not only was the nitrogen removal efficiency affected by the low concentration of $\mathrm{GO}$, but the phosphate $\left(\mathrm{PO}_{4}^{3-}\right)$ removal effect was also slightly changed. Ahmed F. et al. demonstrated that the significant effect of GO on PAO microbial community was observed at higher concentrations of $\mathrm{GO}$ (200-300 $\mathrm{mg} / \mathrm{L})$ [24], but missing data of longterm accumulation of low concentration $\mathrm{GO}$ for

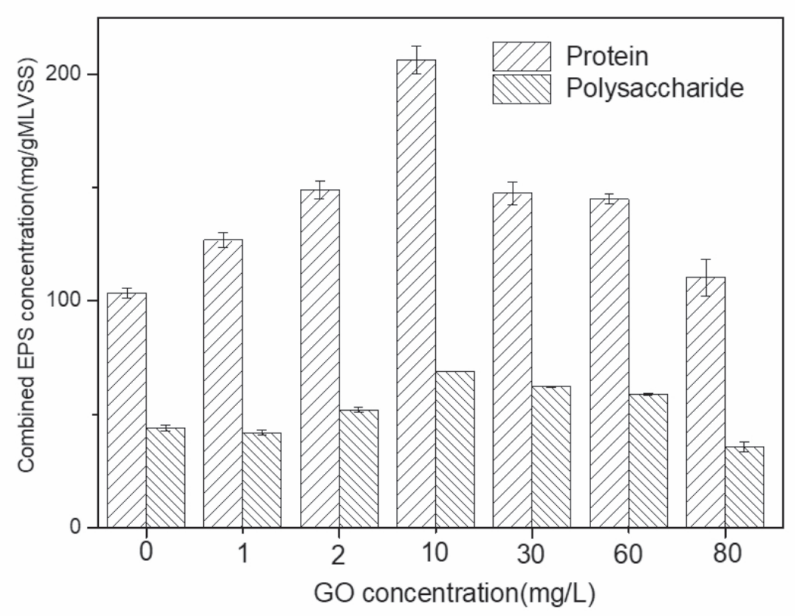

Fig. 2. The concentrations of EPS under the influence of various $\mathrm{GO}$ doses. 
polyphosphate bacteria in activated sludge. As seen in Fig. 1d), the low concentration of GO had a greater effect on the effluent phosphate. With initially GO adding, phosphate concentration increased fast, but could recover quickly. With the increase of GO, the Phosphate content in the effluent increased again, and it was difficult to return to the level of the control group. Until the GO was $15 \mathrm{mg} / \mathrm{L}$, the Phosphate content in the effluent decreased to the control level. When the GO concentration increases again, the Phosphate content in the effluent still increased, and the maximum concentration was $1.72 \mathrm{mg} / \mathrm{L}$ (the influent GO concentration was $60 \mathrm{mg} / \mathrm{L}$ ), lower than the highest phosphate effluent concentration of $2.72 \mathrm{mg} / \mathrm{L}$ (theinfluent GO concentration was $5 \mathrm{mg} / \mathrm{L}$ ). When the concentration of $\mathrm{GO}$ was $80 \mathrm{mg} / \mathrm{L}$, the maximum concentration of Phosphate was $0.911 \mathrm{mg} / \mathrm{L}$, showing that there was still a certain degree of recovery. In the recovery phase of $80-90$ cycles (without GO adding), the content of phosphate could be further reduced, and the effluent Phosphate concentration was about 0.3 , which indicated that microbial community functionality for phosphate removal had been restored. In the environment of high concentration of GO, PAO had adapted to the new environment, and the phosphate removal capacity had recovered basically. In Hai's study, the authors showed that the microbial population was not able to adapt and recover overtime from the high initial dose $(20 \mathrm{mg} / \mathrm{L})$ of nanomaterials [41]. In our study, initial GO concentration was low, and GO concentration was gradually increased, and this allowed the PAO to gradually adapt to the presence of GO and got recovery.

\section{Impact of GO on EPS and SEM Image}

As shown in Fig. 2, the change of PS in EPS was not obvious, and the change of PN had a significant increase and then decrease trend. And according to Shah's study [42], we could clearly identify the existence of GO. The description of EPS change below was all about
PN. EPS contents increased with GO concentration within 1, 2 and $10 \mathrm{mg} / \mathrm{L}$, and the highest EPS of $206.18 \mathrm{mg} / \mathrm{g}$ MLSS occurred at $10 \mathrm{mg} / \mathrm{L} \mathrm{GO}$. It is well known that EPS had a function of resisting toxicants as a protective barrier in some toxic environments [43]. Higher EPS contents indicated that microorganisms were under the inhibition of GO. With the increase concentration of GO from 1 to $10 \mathrm{mg} / \mathrm{L}$ in the influent, the inhibitory effect was increasing gradually. During the 20 cycles of adding 2, $10 \mathrm{mg} / \mathrm{L} \mathrm{GO}$, the ammonia nitrogen concentration had a larger peak compare to the effluent at a higher concentration of GO, indicated that these two concentrations of GO had a greater influence on ammonia removal efficiency during the continuously feeding period. The above result was consistent with the higher concentration of EPS in Fig. 2. This was due to the higher and higher accumulation of GO in activated sludge, which resulted in the inhibition gradually strengthened. COD continued to rise to $29.37 \mathrm{mg} / \mathrm{L}$ after $10 \mathrm{mg} / \mathrm{L}$ GO was added in the experimental group (Fig. 1a).

From the SEM image (Fig. 3), it was found that bacterial cells in the sludge were broken.in low GO concentration $(10 \mathrm{mg} / \mathrm{L})$, which also resulted in the high EPS. As the GO concentration increased to $30 \mathrm{mg} / \mathrm{L}$, the EPS concentration gradually decreased to $147.46 \mathrm{mg} / \mathrm{g}$ MLSS. When the GO concentration was $80 \mathrm{mg} / \mathrm{L}$, the EPS concentration decreased to $110.23 \mathrm{mg} / \mathrm{g}$ MLSS, which was only a little higher than control group of $103.54 \mathrm{mg} / \mathrm{g}$ MLSS. The results meant that although GO centration in the influent increased, the inhibitory effect was attenuated. The possible explanations may be: (1) With the accumulation of GO, some microorganisms adapted to the new situation and reproduced; while some others couldn't survive which lead to the decrease in community richness and diversity (Table 3). As a result, the EPS reduced compared to the initial situation and the inhibition weakened. (2) When the GO concentration was $60 \mathrm{mg} / \mathrm{L}$, microorganisms attached on the GO and no rupture occurred, which was consistent with EPS
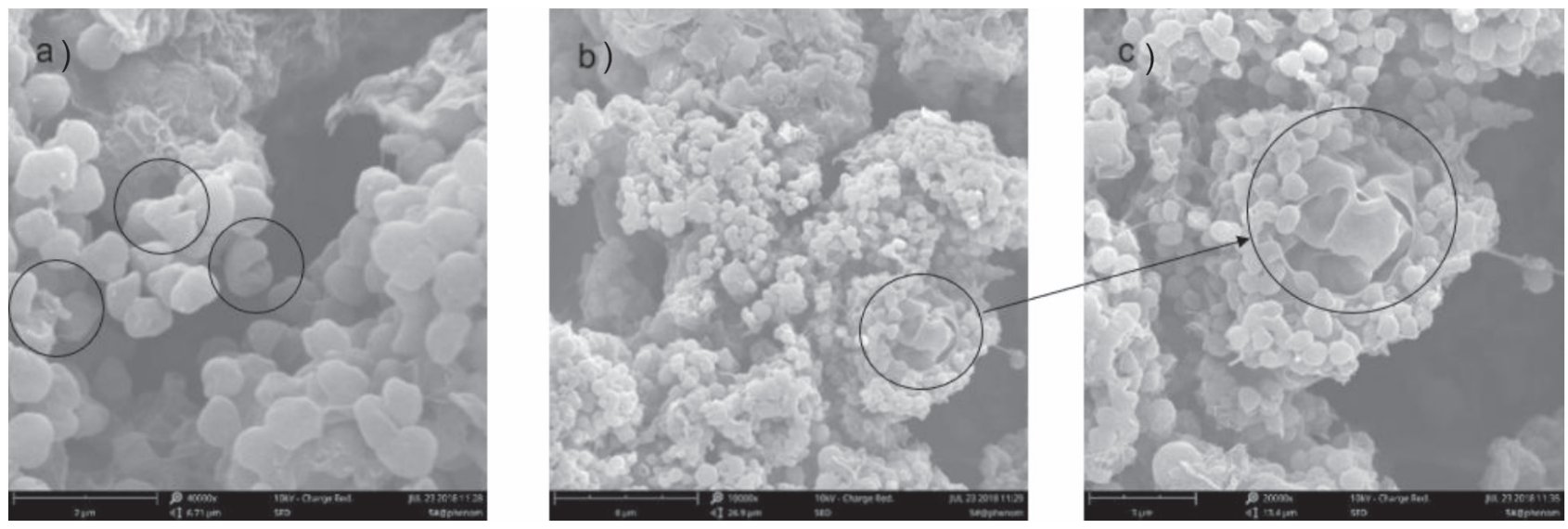

Fig. 3. SEM image of Activated sludge with GO. a) activated sludge with a concentration of $10 \mathrm{mg} / \mathrm{L}$ (Bacterial rupture); b), c) activated sludge with a concentration of $60 \mathrm{mg} / \mathrm{L}$ (Microbial community attached to GO). 
Table 3. Bacterial alpha diversity index statistics.

\begin{tabular}{|c|c|c|c|c|c|c|c|}
\hline Sample ID & Seq num & OTU num & ACE index & Chao index & Shannon index & Simpson & Coverage \\
\hline Control reactor & 68798 & 4771 & 60396.92 & 26951.18 & 5.16 & 0.03 & 0.95 \\
\hline $10 \mathrm{mg} / \mathrm{LGO}$ & 51072 & 3416 & 47685.87 & 22229.91 & 4.42 & 0.09 & 0.95 \\
\hline $60 \mathrm{mg} / \mathrm{LGO}$ & 69669 & 3434 & 46427.71 & 25943.37 & 4.11 & 0.14 & 0.96 \\
\hline $80 \mathrm{mg} / \mathrm{LGO}$ & 69948 & 1560 & 8167.65 & 4994.27 & 2.44 & 0.33 & 0.99 \\
\hline Without GO & 82935 & 2067 & 13328.51 & 7140.02 & 3.15 & 0.24 & 0.98 \\
\hline
\end{tabular}

decrease. Baek's results [44] showed that bacteria was easy to adsorbed on GO layers. In our study, only when the GO concentration was high enough the GO layer could form and the inhibition could decrease. And as the Table S2 shows that almost all GO was adsorbed into activated sludge.

Considered with the SEM image (Fig. 3a-c), it could be seen that there were signs of bacterial cell destruction in the activated sludge at low concentration of GO. In the image with GO $60 \mathrm{mg} / \mathrm{L}$, the microorganism adhered to the surface of the large piece of graphene oxide sheet, which reduced the damage of the bacteria $[45,46]$. There are obvious wrinkles on the GO's surface, maybe it was speculated that high concentration of GO had less inhibitory effect on phosphorus removal [47].

\section{Changes in the Sludge Functional Microbial Communities Exposed to GO}

As shown in Table 2, 51072-82935 effective sequences for five activated sludge samples were obtained by $16 \mathrm{~S}$ rRNA Metagenomics sequencing, and the effective sequence ratio was higher than $95 \%$. The library size of each sample was normalized to
51072 sequences, which was the lowest number of sequences among the five samples. There were total of 15248 OTUs recovered from five activated sludge samples. The coverage values of the five samples were greater than 0.95 , which indicated that the sequences covered most the community diversities of these samples. It was obvious that the numbers of OTUs, ACE, Chao, Shannon and Simpson indexes of the five samples were different from each other, suggesting that long-term addition of increased concentration of GO in the influent certainly impacted the microbial communities. Especially, the OTU number decreased from 4771 to 3416 with $\mathrm{GO}$ concentration increased from 0 to $10 \mathrm{mg} / \mathrm{L}$, then decreased from 3434 to 1560 with $\mathrm{GO}$ concentration increased from 60 to $80 \mathrm{mg} / \mathrm{L}$, demonstrating that increasing GO could weaken the abundance and species richness in this activated sludge systems. Similarly, when GO concentration varied from 0 to $80 \mathrm{mg} / \mathrm{L}$, the values of $\mathrm{ACE}$, Chao, and Shannon also indicated decreased tendencies. However, the OTU number increased from 1560 to 2067 as the GO concentration decreased from $80 \mathrm{mg} / \mathrm{L}$ to Without GO, which suggested no longer add GO would strengthen the abundance and species richness. Similarly, the a)

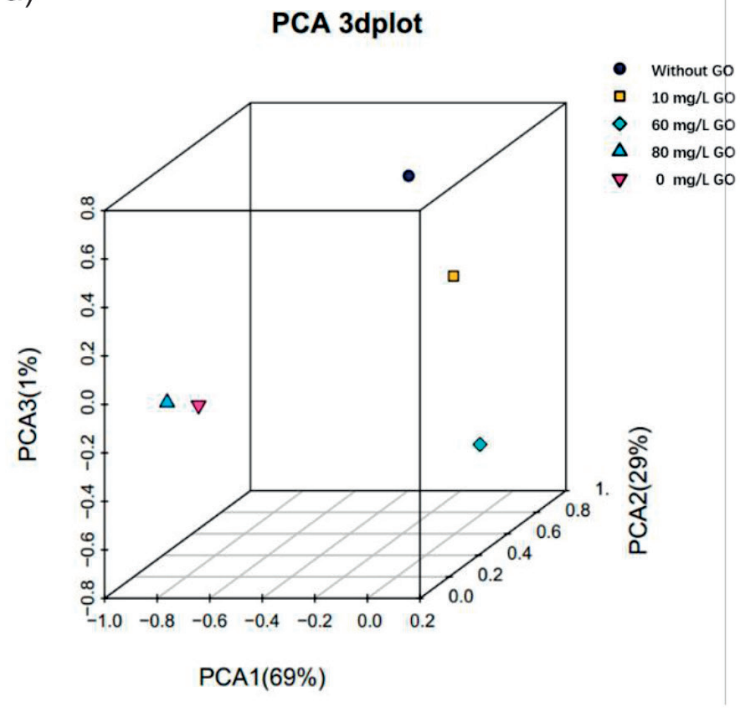

b)

Distribution Barplot

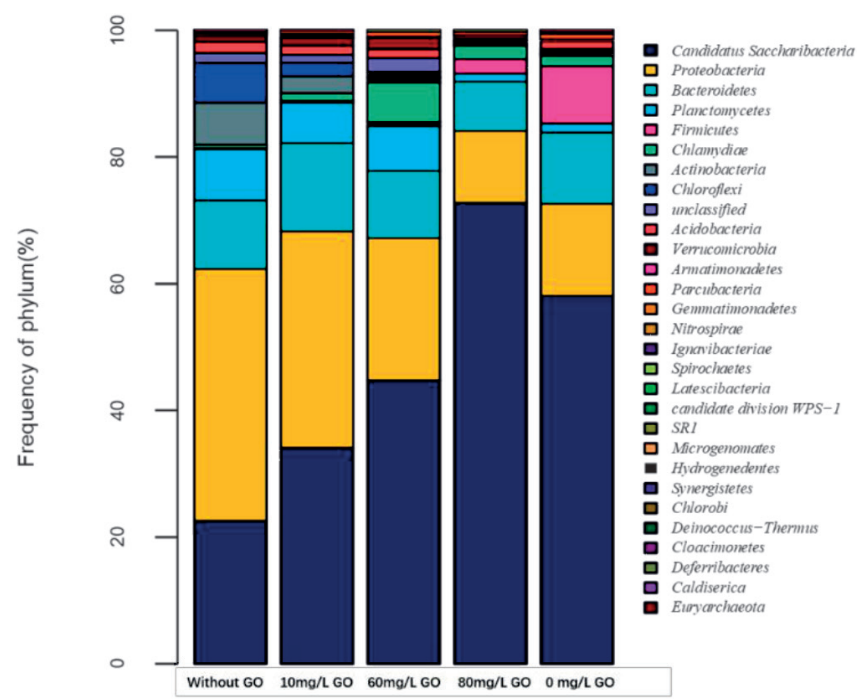

Fig. 4. Community structure of activated sludge system. a) Principal Component Analysis plots of five activated sludge samples. b) Microbial community distribution at the phylum level in each sample. 
Table 4. Relative abundances of potential functional groups in test reactor.

\begin{tabular}{|c|c|c|c|c|c|c|}
\hline Function categories & Genius name & $\begin{array}{c}\text { Control reactor } \\
(\%)\end{array}$ & $\begin{array}{l}10 \mathrm{mg} / \mathrm{L} \\
\mathrm{GO}(\%)\end{array}$ & $\begin{array}{l}60 \mathrm{mg} / \mathrm{L} \\
\mathrm{GO}(\%)\end{array}$ & $\begin{array}{l}80 \mathrm{mg} / \mathrm{L} \\
\mathrm{GO}(\%)\end{array}$ & $\begin{array}{c}\text { Without GO } \\
(\%)\end{array}$ \\
\hline GAO & Defluviicoccus & 9.46 & 9.57 & 1.13 & 0.37 & 0.54 \\
\hline \multirow{3}{*}{ Bulking bacteria } & Acinetobacter & 0.08 & 0.03 & 0 & 0.08 & 1 \\
\hline & Chryseobacterium & 0 & 0.14 & 0 & 0 & 0 \\
\hline & & 0.08 & 0.17 & 0 & 0.08 & 1 \\
\hline \multirow{10}{*}{ Denitrifier } & Zoogloea & 0.16 & 0.13 & 0.22 & 0.2 & 0.45 \\
\hline & Thauera & 0 & 0.07 & 0.12 & 0.11 & 0.2 \\
\hline & Pseudomonas & 0.02 & 0 & 0 & 0.04 & 0.34 \\
\hline & Hyphomicrobium & 0.15 & 0.05 & 0.09 & 0.04 & 0.03 \\
\hline & Acidovorax & 0.1 & 0.02 & 0.06 & 0.01 & 0.01 \\
\hline & Flavobacterium & 0.02 & 0.05 & 0.01 & 0 & 0 \\
\hline & Curvibacter & 0.01 & 0.01 & 0 & 0 & 0 \\
\hline & Methylophilus & 0 & 0 & 0.01 & 0.01 & 0 \\
\hline & Paracoccus & 0.01 & 0 & 0 & 0 & 0 \\
\hline & & 0.47 & 0.33 & 0.51 & 0.41 & 1.03 \\
\hline \multirow{2}{*}{$\mathrm{NOB}$} & Nitrospira & 0.17 & 0.12 & 0.21 & 0.07 & 0.18 \\
\hline & & 0.17 & 0.12 & 0.21 & 0.07 & 0.18 \\
\hline \multirow{3}{*}{$\mathrm{AOB}$} & Nitrosomonas & 0.01 & 0 & 0.01 & 0.02 & 0.02 \\
\hline & Nitrosospira & 0.01 & 0 & 0 & 0 & 0 \\
\hline & & 0.02 & 0 & 0.01 & 0.02 & 0.02 \\
\hline
\end{tabular}

values of ACE, Chao and Shannon also indicated increased tendencies.

PCA (Principal Component Analysis) analysis was completed on the OTU composition of five samples, and the result is shown in Fig. 4a). The contribution rate of principal component 1 (PCA1), principal component 2 (PCA2), and principal component 3 (PCA3) in Fig. 4 were respectively $69 \%, 29 \%$ and $1 \%$. As shown in Fig. 4a), The OTU composition of the activated sludge system at different GO concentrations was quite different, hence the microbial community structure was visibly different. However, the community structure shift was in accordance with the slow changes in flux and biofilm structure at the control reactor. It indicated that the impact of GO to activated sludge system was not permanent.

Five microbial samples at different GO concentrations were analyzed to reveal changes in microbial communities at the phylum level (Fig. 4b). Among the detected 26 known phyla, the relative abundance higher than in each sample were mainly Proteobacteria (11.39\% 39.8\%), Candidatus Saccharibacteria $\quad(22.55 \% \sim 72.75 \%), \quad$ Bacteroidetes (7.75\% 13.87\%) and Planctomycetes (1.42\% 8.14\%). The relative abundance of Proteobacteria in five samples was in order from large to small successively
Control reactor, $10 \mathrm{mg} / \mathrm{L} \mathrm{GO}, 60 \mathrm{mg} / \mathrm{L} \mathrm{GO}$, Without GO, $80 \mathrm{mg} / \mathrm{L}$ GO. The relative abundance of Candidatus Saccharibacteria in activated sludge system when influent GO concentration reach $80 \mathrm{mg} / \mathrm{L}$ was the highest, while the relative abundance of Planctomycetes, Chloroflexi and Actinobacteria decreased with the GO concentration increasing.

Candidatus Saccharibacteria and Proteobacteria had the highest relative abundance in five samples, they were common dominant phylum in the wastewater treatment process. The experiments of Caroline Kragelund et al. [48] revealed that Chloroflexi constituted a specialized group of filamentous bacteria only active under aerobic conditions consuming primarily carbohydrates. The abundance of Chloroflexi decreased with GO concentration increased, which resulted in high effluent COD. In addition, the phyla such as Chlamydiae, Planctomycetes, Acidobacteria and Gemmatimonadetes were also detected. They all played an important role in the wastewater treatment process though their relative abundance was not high enough.

Table 4 shows the main microbial structure and distribution at genus level in five samples. Among the 324 detected genera, Defluviicoccus belonging to glycogen nonpolyphosphate-accumulating organism 


\section{heatmap of genus}

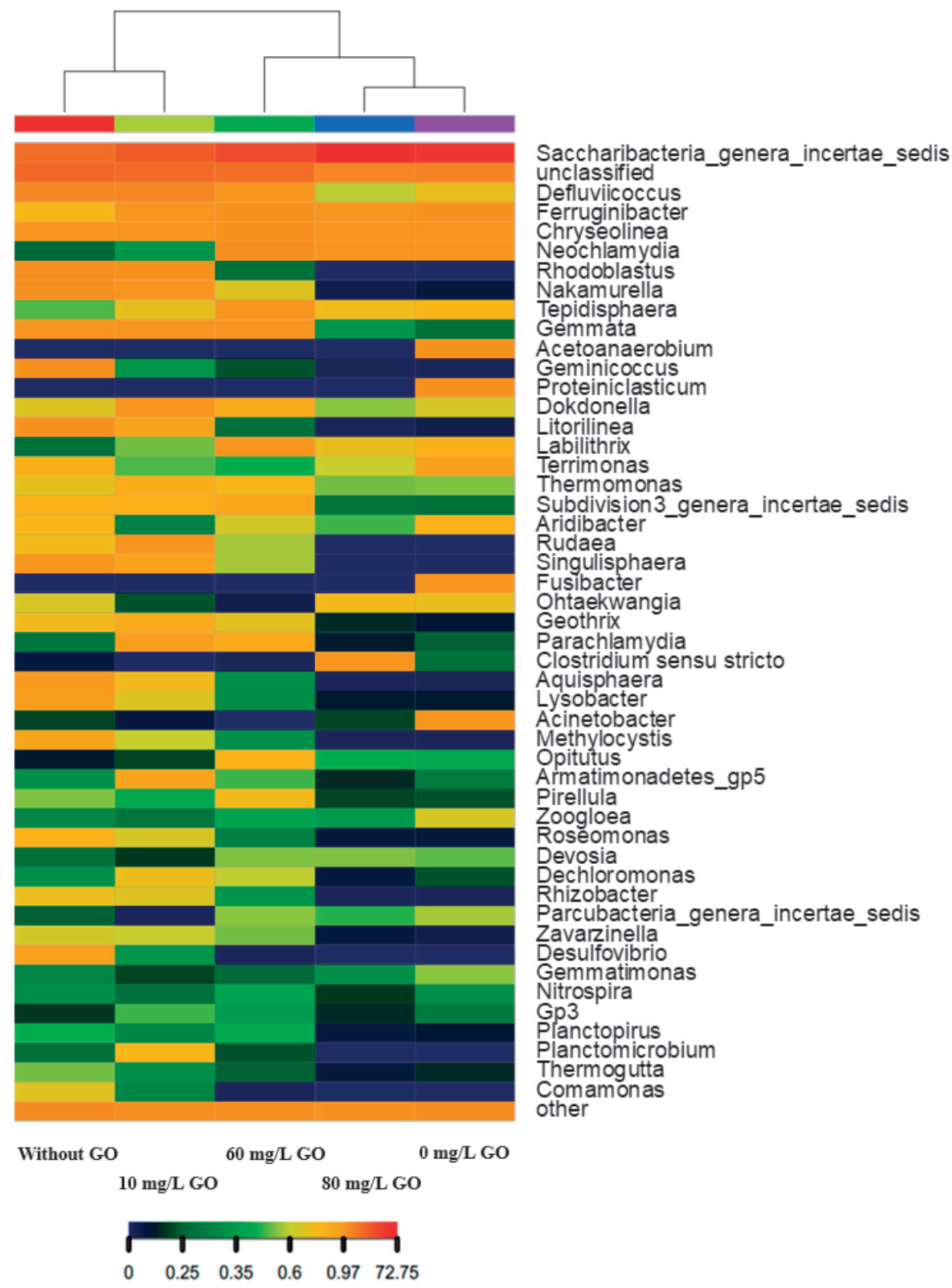

Fig. 5. Heatmap of relative abundances of different genera in the reactors with different concentrations of GO. Color scale from Blue (lowest abundance) to Red (highest abundance).

(GAO), which has competition relationship with polyphosphate-accumulating organisms (PAO). Combine Fig. 5 with Fig. 1d), the abundance of Defluviicoccus was decreasing constantly, this also indirectly indicated the system environment was more suitable for the growth and reproduction of PAO, which was consistent with the increase in phosphate removal efficiency. Nitrosomonas and Nitrosospira were two types of $\mathrm{AOB}$ detected in this study, the small change in quantity was not enough to explain the impact of $\mathrm{GO}$ on it. The abundance of NOB, i.e., Nitrospira was decreased as the concentration of GO increased to 10 $\mathrm{mg} / \mathrm{L}$, which was in good agreement with the TN removal efficiency. Some types of Denitrifier such as Zoogloea, Thauera, Pseudomonas, Hyphomicrobium and Acidovorax were also detected. Zoogloea and Thauera was less affected. The overall results showed that the GO solution with increasing concentration has a great influence on various functional bacteria in the activated sludge, which changes the community composition of the microorganisms. The q-PCR was conducted to evaluate the abundances of denitrifying 


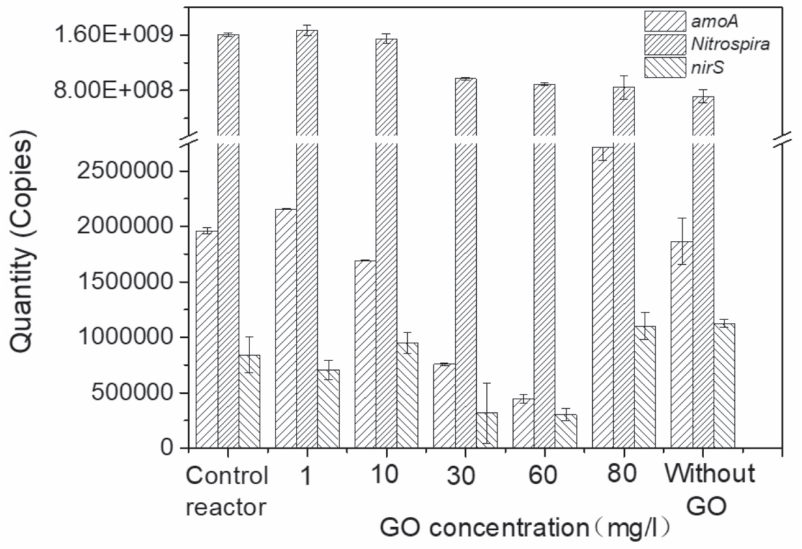

Fig. 6. Quantitative abundances of genes amoA, Nitrospira, nirS at different GO concentrations.

functional genes nir $\mathrm{S}, \mathrm{AOB}$ genes amoA and $\mathrm{NOB}$ genes Nitrospira during the sewage treatment process with GO increased from 0 to $80 \mathrm{mg} / \mathrm{L}$ and 10 cycles recovery phase (Fig.6). The three genes showed no obvious changes when GO concentration was $1 \mathrm{mg} / \mathrm{L}$. When GO concentration was increased to $60 \mathrm{mg} / \mathrm{L}$, the abundances of gene amoA and nirS obviously decreased to $4.43 \times 10^{\wedge} 5$ copies and $3.02 \times 10^{\wedge} 5$ copies, respectively, while the decrease tendency of Nitrospira presented relatively slight. These results suggested that nitrate reduction ability and ammonia-oxidizing ability were both decreased under high GO concentration, which also indicated that long-term exposure high concentration inhibited the abundances of denitrifying functional genes and $\mathrm{AOB}$ genes.

\section{Conclusion}

This study investigated the impacts of GO on biological performance and activated sludge microbiota. The conclusions were as follows:

1) In conclusion, $\mathrm{GO}$ had a significant impact on $\mathrm{COD}$ removal efficiency and the highest effluent COD contents occurred when influent GO concentration was $30 \mathrm{mg} / \mathrm{L}$. Low concentration of GO (1-10 mg/L) had a greater impact on ammonia and phosphate removal performance. And due to the adaption of microorganisms, when the GO concentration is $60 \mathrm{mg} / \mathrm{L}$ and $80 \mathrm{mg} / \mathrm{L}$, the phosphate and nitrogen removal efficiency are slightly affected.

2) As GO entered the activated sludge system and combines with it, it adsorbed a large number of microorganisms on the GO surface.

3) As the GO concentration of the influent increased, GO was almost entirely accumulated in the activated sludge, which changed the community structure. Responses of different populations to different GO concentrations were not exactly the same. Kinds of denitrifier were enriched when influent GO was
$80 \mathrm{mg} / \mathrm{L}$, which resulted in the lower TN content in the effluent than that of the control reactor. Since $\mathrm{GO}$ was not detected in the effluent, the existence of forms and transformation of GO in the sludge will be taken into account in the future study.

\section{Supplementary Data}

The following are the supplementary data related to this article: Removal performances of organic and nutrient in the test SBR (Table S1). The quality of GO influent and effluent (Table S2).

\section{Acknowledgement}

This project was supported by National Natural Science Foundation of China (Grant No. 51708140, 51478127), Graduate Innovative Ability Training Funding Program of Guangzhou University (2018GDJC-M01).

\section{Conflict of Interest}

The authors declare no conflict of interest.

\section{References}

1. CHEN Y., PÖTSCHKE P., PIONTECK J., VOIT B., QI H. Smart cellulose/graphene composites fabricated by in situ chemical reduction of graphene oxide for multiple sensing applications. Journal of Materials Chemistry A, 6 (17), 7777, 2018.

2. HE X., LIU Q., WANG J., CHEN H. Wearable gas/strain sensors based on reduced graphene oxide/linen fabrics [J]. Frontiers of Materials Science, 13 (3), 305, 2019.

3. CAO M., ZHAO W., WANG L., LI R., GONG H., ZHANG Y., XU H., LU J. Graphene Oxide-Assisted Accumulation and Layer-by-Layer Assembly of Antibacterial Peptide for Sustained Release Applications. ACS Applied Materials \& Interfaces, 10 (29), acsami.8b07417-, 2018.

4. KAZEMPOUR M., NAMAZI H., AKBARZADEH A., KABIRI R., Synthesis and characterization of PEGfunctionalized graphene oxide as an effective $\mathrm{pH}$ - sensitive drug carrier [J]. Artificial Cells, Nanomedicine, and Biotechnology, 47 (1), 90, 2019.

5. FAN L., LUO C. SUN M., QIU H., LI X. Synthesis of magnetic $\beta$-cyclodextrin-chitosan/graphene oxide as nanoadsorbent and its application in dye adsorption and removal. Colloids \& Surfaces B Biointerfaces, 103 (6), 601, 2013

6. FAKIR A.A.E., ANFAR Z., BENAFQIR M., JADA A., ALEM N.E. Polyaniline coated hematite sand supported on graphene oxide (HS@PANI-GO) as a new magnetic material for advanced catalytic oxidation based on sulfate radicals: Optimization using response surface methodology [J]. Journal of Chemical Technology \& Biotechnology, 94 (8), 2609, 2019. 
7. ZHU H., XU X., ZHONG X. Adsorption of Co(II) on Graphene Oxides from Aqueous Solution[J]. Polish Journal of Environmental Studies, 25 (6), 2675, 2016.

8. SHERLALA A.I.A., RAMAN A.A.A., BELLO M.M., ASGHAR A. A review of the applications of organofunctionalized magnetic graphene oxide nanocomposites for heavy metal adsorption[J]. Chemosphere, 193, 1004, 2017.

9. LIU C.,WU T., HSU P.C., XIE J., ZHAO J., LIU K., SUN J., XU J., TANG J., YE Z. Direct/Alternating Current Electrochemical Method for Removing and Recovering Heavy Metal from Water Using Graphene Oxide Electrode [J]. ACS Nano, 13 (6), 6431, 2019.

10. TAO X., WANG X., LI Z., ZHOU S. Ultralow temperature synthesis and improved adsorption performance of graphene oxide nanosheets[J]. Applied Surface Science, 324, 363, 2015.

11. XU L., MA R., SUN C., SUN D. Enterococcus faecalis Bioflocculant Enhances Recovery of Graphene Oxide from Water[J]. Polish Journal of Environmental Studies, 27 (6), 2811, 2018.

12. WENDI Z., CHI W., LI Z., LU Z., LI Y., JUN-JIE Y., YU-TING Z., XINGFA G., YING F., GUANGJUN N. Unraveling stress-induced toxicity properties of graphene oxide and the underlying mechanism[J]. Advanced Materials, 24 (39), 5391, 2012.

13. SEABRA A.B., PAULA A.J., RENATA D.L., ALVES O.L., NELSON D. Nanotoxicity of graphene and graphene oxide[J]. Chemical Research in Toxicology, 27 (2), 159, 2014.

14. LIAO K.H., LIN Y.S., MACOSKO C.W., HAYNES C.L. Cytotoxicity of Graphene Oxide and Graphene in Human Erythrocytes and Skin Fibroblasts[J]. Acs Appl Mater Interfaces, 3 (7), 2607, 2011.

15. ZHANG W., YAN L., LI M., ZHAO R., YANG X., JI T., GU Z., YIN J., GAO X., NIE G. Deciphering the underlying mechanisms of oxidation-state dependent cytotoxicity of graphene oxide on mammalian cells. Toxicology Letters, 237 (2), 61, 2015.

16. PALMER B.C., PHELAN-DICKENSON S.J., DELOUISE L.A. Multi-walled carbon nanotube oxidation dependent keratinocyte cytotoxicity and skin inflammation[J]. T Particle and Fibre Toxicology, 16 (1), 3, 2019

17. LIU Y., ZHANG Y., ZHANG T., JIANG Y., LIU $\mathrm{X}$. Synthesis, characterization and cytotoxicity of phosphorylcholine oligomer grafted graphene oxide[J]. Carbon, 71, 166, 2014.

18. WANG D., WANG G., ZHANG G., XU X., YANG F. Using graphene oxide to enhance the activity of anammox bacteria for nitrogen removal[J]. Bioresour Technol, 131, 527, 2013.

19. KIM M.J., KO D., KO K., KIM D., JI Y.L., SANG M.W., KIM W., CHUNG H. Effects of silver-graphene oxide nanocomposites on soil microbial communities[J]. Journal of Hazardous Materials, 346, 93, 2018.

20. OMID A., ELHAM G. Toxicity of graphene and graphene oxide nanowalls against bacteria[J]. Acs Nano, 4 (10), 5731, 2010.

21. NGUYEN H.N., RODRIGUES D.F. Chronic toxicity of graphene and graphene oxide in sequencing batch bioreactors: A comparative investigation[J]. J Hazard Mater, 343, 200-, 2018.

22. LIU X., ZHAO Y., LUO Y., WANG Y., WANG X. Effect of Graphene Oxide on the Characteristics and Mechanisms of Phosphorus Removal in Aerobic Granular Sludge: Case Report[J]. Water, Air, \& Soil Pollution, 229 (1), 2017.
23. GUO C., WANG Y., LUO Y., CHEN X., LIN Y., LIU X. Effect of graphene oxide on the bioactivities of nitrifying and denitrifying bacteria in aerobic granular sludge[J]. Ecotoxicology \& Environmental Safety, 156, 287, 2018.

24. AHMED F., RODRIGUES D.F. Investigation of acute effects of graphene oxide on wastewater microbial community: a case study[J]. Journal of Hazardous Materials, 256-257 (1), 33, 2013.

25. INDRANIL C., DUCH M.C., MANSUKHANI N.D., HERSAM M.C., DERMONT B. Colloidal properties and stability of graphene oxide nanomaterials in the aquatic environment[J]. Environmental Science \& Technology, 47 (12), 6288, 2013.

26. ZENG Q., LI Y., YANG S. Sludge Retention Time as a Suitable Operational Parameter to Remove Both Estrogen and Nutrients in an Anaerobic-Anoxic-Aerobic Activated Sludge System[J]. Environmental Engineering Science, 30 (4), 161, 2013.

27. SHAN S.J., ZHAO Y., TANG H., CUI F.Y. A Minireview of Carbonaceous Nanomaterials for Removal of Contaminants from Wastewater[J]. IOP Conference Series: Earth and Environmental Science, 68 (1), 012003, 2017.

28. China Environmental Science Press, B., China, Water and Waste-water Monitoring and Analysis Methods. National Environmental Protection Agency[J], Editor of water and wastewater monitoring and analysis methods, 1997.

29. SHENG G.P., YU H.Q., LI X.Y. Extracellular polymeric substances (EPS) of microbial aggregates in biological wastewater treatment systems: a review. Biotechnology Advances, 28 (6), 882, 2010.

30. WANG R., PENG Y., CHENG Z., REN N. Understanding the role of extracellular polymeric substances in an enhanced biological phosphorus removal granular sludge system[J]. Bioresour Technol, 169 (5), 307, 2014.

31. CHEN H., ZHENG X., CHEN Y., LI M., LIU K., LI $\mathrm{X}$. Influence of Copper Nanoparticles on the PhysicalChemical Properties of Activated Sludge[J]. Plos One, 9 (3), e92871, 2014.

32. KOWALCHUK G.A., STEPHEN J.R. BOER W, DE., PROSSER J.I., EMBLEY T.M., WOLDENDORP J.W. Analysis of ammonia-oxidizing bacteria of the beta subdivision of the class Proteobacteria in coastal sand dunes by denaturing gradient gel electrophoresis and sequencing of PCR-amplified $16 \mathrm{~S}$ ribosomal DNA fragments[J]. Appl Environ Microbiol, 63 (4), 1489, 1997.

33. DIONISI H.M., LAYTON A.C., GERDA H., GREGORY I.R., ROBINSON K.G., SAYLER G.S. Quantification of Nitrosomonas oligotropha-like ammonia-oxidizing bacteria and Nitrospira spp. from full-scale wastewater treatment plants by competitive PCR $[\mathrm{J}]$. Applied \& Environmental Microbiology, 68 (1), 245, 2002.

34. MICHOTEY V., MÉJEAN V., BONIN P. Comparison of methods for quantification of cytochrome $\operatorname{cd}(1)$ denitrifying bacteria in environmental marine samples[J]. Applied \& Environmental Microbiology, 66 (4), 1564, 2000.

35. THROBACK I., K. ENWALL, A., HALLIN S. Reassessing PCR primers targeting nirS, nirK and nosZ genes for community surveys of denitrifying bacteria with DGGE[J]. Fems Microbiology Ecology, 49 (3), 401, 2010.

36. LI L., KONG X. Experimental study on the treatment of high $\mathrm{Cl}$-high $\mathrm{Ca} \sim(2+)$ and high $\mathrm{COD}$ wastewater by activated sludge process[J]. Industrial Water Treatment, 31 (11), 74, 2011.

37. HAI R., WANG Y., WANG X., DU Z., LI Y. Impacts of Multiwalled Carbon Nanotubes on Nutrient Removal 
from Wastewater and Bacterial Community Structure in Activated Sludge[J]. e107345, 2014.

38. NGUYEN H.N., C.-W.S.L., RODRIGUES D.F., Acute toxicity of graphene nanoplatelets on biological wastewater treatment process $[\mathrm{J}]$. Environ. Sci.: Nano, 4 (1), 160, 2017.

39. NGUYEN H.N., R.D.F., Chronic toxicity of graphene and graphene oxide in sequencing batch bioreactors: A comparative investigation[J]. Journal of Hazardous Materials, 343, 200, 2018.

40. DODDS W.K., SMITH V.H. Nitrogen, phosphorus, and eutrophication in streams[J]. Inland Waters, 6 (2), 155, 2016.

41. HAI R., WANG Y., WANG X., DU Z., LI Y. Impacts of multiwalled carbon nanotubes on nutrient removal from wastewater and bacterial community structure in activated sludge[J]. Plos One, 9 (9), e107345, 2014.

42. SHAH R., KAUSAR A., MUHAMMAD B. Characterization and Properties of Poly(methyl methacrylate)/Graphene, Poly(methyl methacrylate)/ Graphene Oxide and Poly(methyl methacrylate)/pPhenylenediamine-Graphene Oxide Nanocomposites[J]. Journal of Macromolecular Science: Part D - Reviews in Polymer Processing, 54 (13), 1334, 2015.

43. HOU W., MA Z., SUN L., HAN M., LU J., LI Z., MOHAMAD O.A., WEI G. Extracellular polymeric substances from copper-tolerance Sinorhizobium meliloti immobilize $\mathrm{Cu}^{2+}[\mathrm{J}]$. Journal of Hazardous Materials, 261 (20), 614, 2013.

44. BAEK C., C.S.H., KIM J., YOON S., MIN J. Bacterial Adsorption on Nano Graphene Oxide-Coated Microbeads for Molecular Diagnosis[J]. Journal of Nanoscience \& Nanotechnology, 16 (11), 11887, 2016.

45. WANG J., CHEN B. Adsorption and coadsorption of organic pollutants and a heavy metal by graphene oxide and reduced graphene materials. Chemical Engineering Journal, 281, 379, 2015.

46. ZHANG X., GONG Y., JIA S., QIN C. Co-adsorption of an anionic dye in the presence of a cationic dye and a heavy metal ion by graphene oxide and photoreduced graphene oxide[J]. RSC Advances, 9 (10), 5313, 2019.

47. LI X., ZHOU H., WU W., WEI S., XU Y., KUANG Y. Studies of heavy metal ion adsorption on Chitosan/ Sulfydryl-functionalized graphene oxide composites[J]. J Colloid Interface Sci, 448, 389, 2015.

48. CAROLINE K., CATERINA L., ARJAN B., KARIN T., DICK E., VALTER T., YUNHONG K., JAAP V.D.W., JANNEKE K., SIMONA R. Identity, abundance and ecophysiology of filamentous Chloroflexi species present in activated sludge treatment plants[J]. Fems Microbiology Ecology, 59 (3), 671, 2007. 


\section{SUPPLEMENTARY MATERIAL}

Table S1. Removal performances of organic and nutrient in the test SBR.

\begin{tabular}{|c|c|c|c|c|}
\hline Items & $\begin{array}{c}\mathrm{GO} \\
(\mathrm{mg} / \mathrm{L})\end{array}$ & Test & Control & $P$-value \\
\hline \multirow{9}{*}{ COD } & 1 & $11.61 \pm 2.67$ & $5.87 \pm 1.13$ & 0.000 \\
\hline & 2 & $11.21 \pm 4.44$ & $5.87 \pm 1.13$ & 0.003 \\
\hline & 5 & $17.09 \pm 8.54$ & $5.87 \pm 1.13$ & 0.001 \\
\hline & 10 & $19.22 \pm 7.44$ & $6.14 \pm 1.29$ & 0.000 \\
\hline & 15 & $20.56 \pm 6.55$ & $6.14 \pm 1.29$ & 0.000 \\
\hline & 30 & $42.52 \pm 12.05$ & $5.60 \pm 0.84$ & 0.000 \\
\hline & 60 & $37.40 \pm 5.71$ & $6.14 \pm 1.29$ & 0.000 \\
\hline & 80 & $21.89 \pm 4.89$ & $6.14 \pm 1.29$ & 0.000 \\
\hline & 0 & $12.02 \pm 4.96$ & $6.14 \pm 1.29$ & 0.003 \\
\hline \multirow{9}{*}{$\mathrm{NH}_{4}^{+}-\mathrm{N}$} & 1 & $3.61 \pm 4.89$ & $0.53 \pm 0.09$ & 0.075 \\
\hline & 2 & $4.94 \pm 3.47$ & $0.42 \pm 0.16$ & 0.001 \\
\hline & 5 & $2.28 \pm 2.61$ & $0.53 \pm 0.10$ & 0.059 \\
\hline & 10 & $3.79 \pm 3.44$ & $0.42 \pm 0.16$ & 0.008 \\
\hline & 15 & $0.90 \pm 1.24$ & $0.53 \pm 0.10$ & 0.385 \\
\hline & 30 & $0.79 \pm 0.68$ & $0.42 \pm 0.16$ & 0.133 \\
\hline & 60 & $1.41 \pm 1.55$ & $0.30 \pm 0.26$ & 0.048 \\
\hline & 80 & $2.71 \pm 1.52$ & $0.01 \pm 0.03$ & 0.000 \\
\hline & 0 & $0.98 \pm 0.27$ & $0.01 \pm 0.03$ & 0.000 \\
\hline
\end{tabular}

\begin{tabular}{|c|c|c|c|c|}
\hline Items & $\begin{array}{c}\mathrm{GO} \\
(\mathrm{mg} / \mathrm{L})\end{array}$ & Test & Control & $P$-value \\
\hline \multirow{9}{*}{$\mathrm{TN}$} & 1 & $10.60 \pm 4.50$ & $9.61 \pm 0.28$ & 0.518 \\
\hline & 2 & $10.64 \pm 3.02$ & $9.47 \pm 0.31$ & 0.266 \\
\hline & 5 & $9.17 \pm 2.29$ & $9.52 \pm 0.22$ & 0.653 \\
\hline & 10 & $11.88 \pm 3.99$ & $9.45 \pm 0.25$ & 0.085 \\
\hline & 15 & $8.51 \pm 1.45$ & $9.59 \pm 0.24$ & 0.041 \\
\hline & 30 & $8.53 \pm 0.87$ & $9.41 \pm 0.23$ & 0.008 \\
\hline & 60 & $6.97 \pm 2.74$ & $9.33 \pm 0.37$ & 0.019 \\
\hline & 80 & $3.82 \pm 1.59$ & $9.10 \pm 0.26$ & 0.000 \\
\hline & 0 & $6.48 \pm 2.34$ & $8.92 \pm 0.21$ & 0.006 \\
\hline \multirow{9}{*}{$\mathrm{P}$} & 1 & $0.48 \pm 0.81$ & $0.09 \pm 0.13$ & 0.164 \\
\hline & 2 & $0.92 \pm 0.79$ & $0.12 \pm 0.10$ & 0.007 \\
\hline & 5 & $1.13 \pm 0.77$ & $0.05 \pm 0.05$ & 0.000 \\
\hline & 10 & $1.40 \pm 0.78$ & $0.03 \pm 0.02$ & 0.000 \\
\hline & 15 & $0.25 \pm 0.25$ & $0.03 \pm 0.02$ & 0.018 \\
\hline & 30 & $0.71 \pm 0.60$ & $0.03 \pm 0.02$ & 0.003 \\
\hline & 60 & $1.22 \pm 0.51$ & $0.03 \pm 0.02$ & 0.000 \\
\hline & 80 & $0.56 \pm 0.31$ & $0.03 \pm 0.01$ & 0.000 \\
\hline & 0 & $0.16 \pm 0.15$ & $0.01 \pm 0.01$ & 0.009 \\
\hline
\end{tabular}

Table S2. The quality of GO influent and effluent.

\begin{tabular}{|c|c|c|c|}
\hline $\begin{array}{c}\text { GO concentration } \\
(\mathrm{mg} / \mathrm{L})\end{array}$ & Cycle & $\begin{array}{c}\text { Influent } \\
(\mathrm{mg})\end{array}$ & $\begin{array}{c}\text { Effluent } \\
(\mathrm{mg})\end{array}$ \\
\hline \multirow{4}{*}{1} & 1 & 2 & 0 \\
\cline { 2 - 4 } & 2 & 2 & 0 \\
\cline { 2 - 4 } & 3 & 2 & 0 \\
\cline { 2 - 4 } & 4 & 2 & 0 \\
\cline { 2 - 4 } & 5 & 2 & 0 \\
\cline { 2 - 4 } & 6 & 2 & 0 \\
\cline { 2 - 4 } & 7 & 2 & 0 \\
\cline { 2 - 4 } & 8 & 2 & 0 \\
\cline { 2 - 4 } & 9 & 2 & 0 \\
\cline { 2 - 4 } & 10 & 2 & 0 \\
\hline
\end{tabular}

\begin{tabular}{|c|c|c|c|}
\hline $\begin{array}{c}\text { GO concentration } \\
(\mathrm{mg} / \mathrm{L})\end{array}$ & Cycle & $\begin{array}{c}\text { Influent } \\
(\mathrm{mg})\end{array}$ & $\begin{array}{c}\text { Effluent } \\
(\mathrm{mg})\end{array}$ \\
\hline \multirow{4}{*}{2} & 1 & 4 & 0 \\
\cline { 2 - 4 } & 2 & 4 & 0 \\
\cline { 2 - 4 } & 3 & 4 & 0 \\
\cline { 2 - 4 } & 4 & 4 & 0 \\
\cline { 2 - 4 } & 5 & 4 & 0 \\
\cline { 2 - 4 } & 6 & 4 & 0 \\
\cline { 2 - 4 } & 7 & 4 & 0 \\
\cline { 2 - 4 } & 8 & 4 & 0 \\
\cline { 2 - 4 } & 9 & 4 & 0 \\
\cline { 2 - 4 } & 10 & 4 & 0 \\
\hline
\end{tabular}


Wang J., et al.

Table S2. Continued.

\begin{tabular}{|c|c|c|c|}
\hline $\begin{array}{c}\text { GO concentration } \\
(\mathrm{mg} / \mathrm{L})\end{array}$ & Cycle & $\begin{array}{l}\text { Influent } \\
\text { (mg) }\end{array}$ & $\begin{array}{c}\text { Effluent } \\
(\mathrm{mg})\end{array}$ \\
\hline \multirow{16}{*}{5} & 1 & 10 & 0 \\
\hline & 2 & 10 & 0 \\
\hline & 3 & 10 & 0 \\
\hline & 4 & 10 & 0 \\
\hline & 5 & 10 & 1 \\
\hline & 6 & 10 & 1 \\
\hline & 7 & 10 & 1 \\
\hline & 8 & 10 & 0 \\
\hline & 9 & 10 & 0 \\
\hline & 10 & 10 & 0 \\
\hline & 11 & 10 & 0 \\
\hline & 12 & 10 & 0 \\
\hline & 13 & 10 & 0 \\
\hline & 14 & 10 & 0 \\
\hline & 15 & 10 & 0 \\
\hline & 16 & 10 & 0 \\
\hline \multirow{10}{*}{10} & 1 & 20 & 1 \\
\hline & 2 & 20 & 1 \\
\hline & 3 & 20 & 1 \\
\hline & 4 & 20 & 1 \\
\hline & 5 & 20 & 1 \\
\hline & 6 & 20 & 1 \\
\hline & 7 & 20 & 1 \\
\hline & 8 & 20 & 1 \\
\hline & 9 & 20 & 1 \\
\hline & 10 & 20 & 1 \\
\hline \multirow{10}{*}{15} & 1 & 30 & 1 \\
\hline & 2 & 30 & 1 \\
\hline & 3 & 30 & 1 \\
\hline & 4 & 30 & 1 \\
\hline & 5 & 30 & 1 \\
\hline & 6 & 30 & 1 \\
\hline & 7 & 30 & 1 \\
\hline & 8 & 30 & 1 \\
\hline & 9 & 30 & 1 \\
\hline & 10 & 30 & 1 \\
\hline
\end{tabular}

\begin{tabular}{|c|c|c|c|}
\hline $\begin{array}{c}\text { GO concentration } \\
(\mathrm{mg} / \mathrm{L})\end{array}$ & Cycle & $\begin{array}{c}\text { Influent } \\
(\mathrm{mg})\end{array}$ & $\begin{array}{l}\text { Effluent } \\
(\mathrm{mg})\end{array}$ \\
\hline \multirow{10}{*}{30} & 1 & 60 & 1 \\
\hline & 2 & 60 & 1 \\
\hline & 3 & 60 & 1 \\
\hline & 4 & 60 & 1 \\
\hline & 5 & 60 & 1 \\
\hline & 6 & 60 & 1 \\
\hline & 7 & 60 & 1 \\
\hline & 8 & 60 & 1 \\
\hline & 9 & 60 & 1 \\
\hline & 10 & 60 & 1 \\
\hline \multirow{10}{*}{60} & 1 & 120 & 2 \\
\hline & 2 & 120 & 2 \\
\hline & 3 & 120 & 2 \\
\hline & 4 & 120 & 2 \\
\hline & 5 & 120 & 2 \\
\hline & 6 & 120 & 2 \\
\hline & 7 & 120 & 2 \\
\hline & 8 & 120 & 2 \\
\hline & 9 & 120 & 2 \\
\hline & 10 & 120 & 2 \\
\hline \multirow{10}{*}{80} & 1 & 160 & 2 \\
\hline & 2 & 160 & 2 \\
\hline & 3 & 160 & 2 \\
\hline & 4 & 160 & 2 \\
\hline & 5 & 160 & 2 \\
\hline & 6 & 160 & 2 \\
\hline & 7 & 160 & 3 \\
\hline & 8 & 160 & 3 \\
\hline & 9 & 160 & 3 \\
\hline & 10 & 160 & 3 \\
\hline
\end{tabular}

